\title{
Neoumbilicoplasty is a useful adjuvant procedure in abdominoplasty
}

\author{
AA Al-shaham CABS
}

AA Al-shaham. Neoumbilicoplasty is a useful adjuvant procedure in abdominoplasty. Can J Plast Surg 2009;17(4):e20-e23.

BACKGROUND: Neoumbilicoplasties are indicated in congenital conditions associated with umbilical agenesis, umbilical loss due to inflammatory destruction, excision of skin cancer involving the umbilical stump and in surgical procedures for herniorrhaphy, as well as in the rare condition of umbilical endometriosis.

OBJECTIVE: Neoumbilicoplasty is an adjuvant procedure that may be necessary during abdominoplasty with wide myofascial plication, or repair of concomitant hernias of the abdominal wall. The present article justifies sacrificing the umbilicus followed by neoumbilicoplasty in patients with significant wide myofascial plication or concomitant hernias of the abdominal wall.

METHODS: Seventeen patients underwent a combination of abdominoplasty and wide (greater than $10 \mathrm{~cm}$ ) vertical plication of the myofascial complex and required neoumbilicoplasty. The male to female ratio was 1:16; mean age was 44 years, mean weight $94.1 \mathrm{~kg}$ and mean height $160.2 \mathrm{~cm}$. Characteristic body morphology included gross trunk obesity with a prominent anterior abdominal wall.The female patients were multiparous. Sacrificing the umbilici followed by neoumbilicoplasty was required in patients with umbilical hernias and patients who had divarication of the rectus abdominis muscles with short umbilical stumps.

RESULTS: Nine patients had concomitant ventral hernias (52.94\%) and eight patients had divarication of the rectus abdominis muscles with short umbilical stumps (47.05\%). The mean perioperative myofascial plication distance was $15.41 \mathrm{~cm}$ and the gap closure required three to five rows of sutures.

CONCLUSION: Neoumbilicoplasty is a useful adjuvant procedure during abdominoplasty with wide myofascial plication or repair of concomitant hernias of the abdominal wall.

Key Words: Abdominal hernias; Abdominoplasty; Myofascial plication; Musculoaponeurotic plication; Neoumbilicoplasty

$\mathrm{T}_{\mathrm{p}}^{\mathrm{h}}$ he umbilicus is an important and essential aesthetic component in the abdomen. Features of the umbilicus include a centrally placed depressed scar surrounded by skin folds, forming superior hood. The shape is elliptical in vertical direction or T-shaped with the long axis lying vertically in the midline. The umbilical diameter averages $1.5 \mathrm{~cm}$ to $2 \mathrm{~cm}$ (1-3), with conical depression whose apex is tethered to the anterior muscular wall. The usual site for placing the umbilicus is approximately $10 \mathrm{~cm}$ above the pubic incision; alternatively, it can be placed $3 \mathrm{~cm}$ above the line joining the anterior superior iliac spines or at the level of highest point of the iliac crest (3-5).

The aesthetic outcome of the umbilicus is often spoiled by either improper positioning - excessively low placement of the umbilicus during immediate postoperative period - or shallow, flat and deformed in the late postoperative period. Disappointing positioning and shape of the umbilicus, along with periumbilical scarring, are the usual drawbacks of abdominoplasty $(4,6)$.

Reconstruction of a deformed and flat umbilicus by neoumbilicoplasty during umbilical herniorrhaphy was first reported

\section{Néo-ombilicoplastie : Technique d'appoint utile lors de l'abdominoplastie}

HISTORIQUE : La néo-ombilicoplastie est indiquée dans les cas de maladies congénitales associées à l'agénésie ombilicale, à la perte de l'ombilic due à une destruction inflammatoire ou à l'excision d'un cancer de la peau impliquant l'ombilic, lors d'interventions chirurgicales pour cure de hernie, de même que dans de rares situations d'endométriose ombilicale.

OBJECTIF : La néo-ombilicoplastie est une technique d'appoint qui peut être nécessaire lors de l'abdominoplastie avec plicature myofasciale étendue et cure de hernie abdominale concomitante. Le présent article décrit une destruction de la zone ombilicale suivie d'une néo-ombilicoplastie chez des patients ayant subi une plicature myofasciale importante ou une cure de hernie abdominale concomitante.

MÉTHODES : Dix-sept patients ont subi à la fois une abdominoplastie et une plicature verticale large (de plus de $10 \mathrm{~cm}$ ) du complexe myofascial. Le rapport hommes:femmes était de 1,16; l'âge moyen était de 44 ans et le poids et la taille moyens, respectivement de $94,1 \mathrm{~kg}$ et de 1,6 m. La morphologie caractéristique était dominée par une obésité tronculaire grossière, avec abdomen proéminent. Les patientes étaient multipares. L'élimination de l'ombilic suivie de néo-ombilicoplastie a été nécessaire chez les patients qui présentaient des hernies ombilicales et une divarication des muscles droits abdominaux avec moignon ombilical court.

RÉSULTATS : Neuf patients présentaient concomitamment des hernies ventrales $(52,94 \%)$ et huit patients présentaient une divarication des muscles abdominaux droits avec moignon ombilical court (47,05\%). L'ampleur de la plicature myofasciale périopératoire était de $15,41 \mathrm{~cm}$ et la fermeture de la plaie a nécessité de trois à cinq rangées de sutures.

CONCLUSION : La néo-ombilicoplastie est une technique d'appoint utile durant l'abdominoplastie avec plicature myofasciale étendue ou durant la réparation d'hernie abdominale concomitante.

Department of Surgery, Baghdad University, Baghdad, Iraq

Correspondence: Dr Ali AH Al-shaham, Department of Surgery, Faculty of Medicine, UiTM, 40450 Shah Alam, Malaysia.

Telephone 060-173-666-230, fax 603-5544-2831,e-mail alialshaham@yahoo.com

by McMillan in 1955 (7). Other indications for umbilical reconstruction include congenital conditions associated with umbilical agenesis (bladder exstrophy, gastroschisis, omphalocoele, cloacal exstrophy), or umbilical loss due to inflammatory destruction (periumbilical necrotizing fasciitis, umbilical sepsis). Neoumbilicoplasty is also indicated in surgical procedures (umbilical herniorrhaphy, laparotomies) as well as excision for skin cancer involving the umbilical stump (8), and in the rare conditions of umbilical endometriosis (9) (Table 1).

The present article discusses sacrificing the umbilicus followed by neoumbilicoplasty as an adjuvant procedure during abdominoplasty with wide myofascial plication or concomitant hernias of abdominal wall.

\section{METHODS}

A retrospective study of 146 consecutive patients who underwent combined abdominoplasty with plication of the myofascial complex was undertaken in two hospitals. During the period of May 2001 to December 2006, 116 patients were 
TABLE 1

\section{Indications for neoumbilicoplasties}

\begin{tabular}{ll}
\hline Absolute indications & Relative indications \\
\hline Congenital absence & Concomitant periumbilical hernias \\
Bladder extrophy & Significant divarication of the rectus abdominis \\
Gastroschisis & Wide myofascial plication with \\
Omphalocele & ultra-short umbilical stump \\
Cloacal extrophy & Extremely long umbilical stump \\
Patent urachus & Deformed umbilicus \\
Inflamatory destruction & \\
Periumbilical necrotizing & \\
fasciitis & \\
Umbilical sepsis & \\
Pilonidal umbilical sinus & \\
Umbilical endometriosis & \\
Neoplastic & \\
Periumbilical tumours & \\
Traumatic loss
\end{tabular}

identified in Baghdad Private Hospital and 30 patients in Al-kindy Teaching Hospital (Baghdad, Iraq). From these patients, 17 who required sacrifice of the original umbilicus followed by neoumbilicoplasty were selected for the present study.

\section{Patient characteristics}

The male to female ratio was 1:16, and ages ranged between 40 and 52 years, with a mean age of 44 years. Mean weight and height was $94.1 \mathrm{~kg}$ and $160.2 \mathrm{~cm}$ (range $79 \mathrm{~kg}$ to $113 \mathrm{~kg}$ and $153 \mathrm{~cm}$ to $170 \mathrm{~cm}$ ), respectively. Mean abdominal circumference was $109 \mathrm{~cm}$ (range $94 \mathrm{~cm}$ to $130 \mathrm{~cm}$ ) and body mass index ranged from $32.5 \mathrm{~kg} / \mathrm{m}^{2}$ to $39.7 \mathrm{~kg} / \mathrm{m}^{2}$. Characteristic body morphology included gross trunk obesity with prominent anterior abdominal wall and exaggerated lumbar lordosis; the female patients included in the study were multiparous. Clinical examinations revealed anterior abdominal aprons, which overlapped the pubic region partially or totally in standing position. Nine patients had concomitant periumbilical hernia of variable sizes (medium to large). There were varying degrees of divarication of the rectus abdominis muscle in eight patients. Detailed examination revealed flat umbilici in five patients and everted umbilici in four, on top of hernial swelling. The degree of protruded abdominal wall was assessed and marked with the patient standing in profile, and the amount of tissue that could be resected was assessed with the patient in supine position. Placement of scar and the expected final results were discussed with the patients, along with potential morbidity, after which patient consent was obtained.

\section{Operative procedure}

While incising and reflecting the lower abdominal flaps, gentle dissection is required in areas of abdominal hernia because the hernial sac is usually adherent to the already attenuated thin abdominal skin; inadvertent opening of the sac necessitates enlarging the peritoneal exploration. The bowel and mesentery are inspected carefully. After ensuring that no intra-abdominal injuries are present, closure of the peritoneal cavity is accomplished. Further steps in dissecting and reflecting abdominal flaps, up to the costal margin, are conducted. The intended

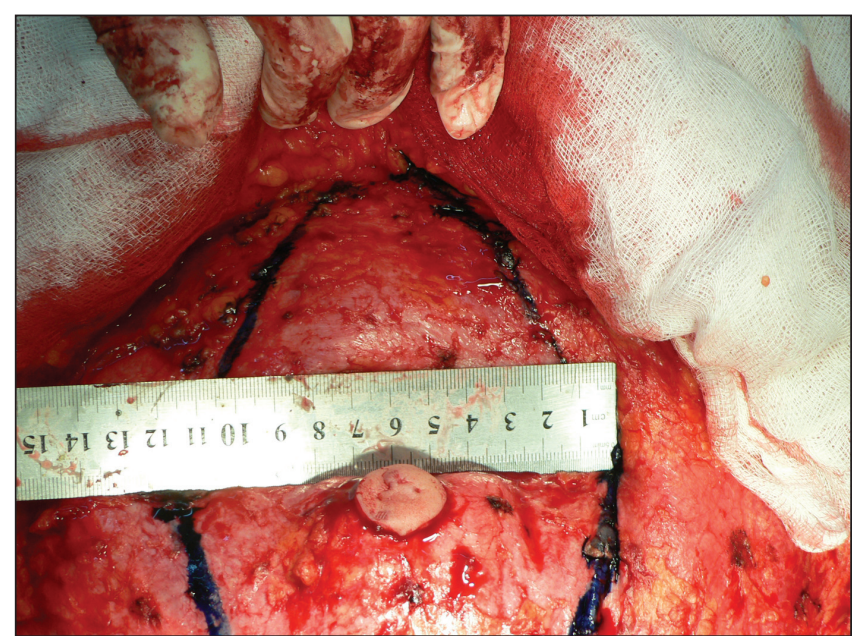

Figure 1) Intended perioperative placation distance can be marked and measured on the anterior abdominal wall

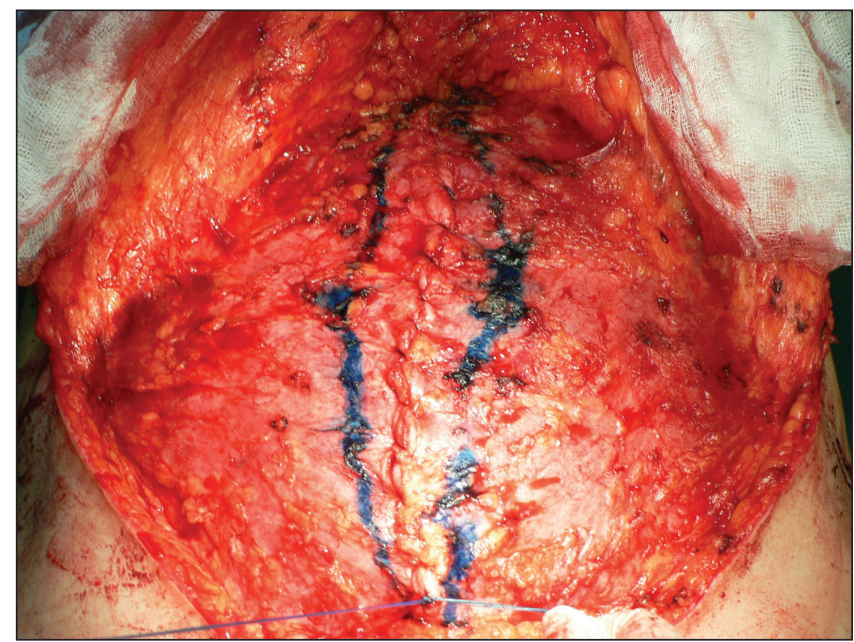

Figure 2) Many rows of sutures are required to accomplish total closure

perioperative plication distances can now be assessed and marked on the anterior abdominal wall (Figure 1). The marking should include the whole distance between xiphisternum and symphysis pubis, keeping in mind that the widest plication is applied to the site of maximum abdominal protrusion. Myofascial plication is performed with number 1 Prolene sutures, and many rows are required to accomplish total gap closure (Figure 2).

Sacrificing the natural umbilicus followed by neoumbilicoplasty is needed (Figure 3) either when short umbilical stumps are encountered or an associated umbilical hernia is present, along with wide myofascial plication distances.

After resection of the adipocutaneous excess lower abdominal flaps, the site of the new umbilicus is marked on the anterior abdominal wall. Conical resection of adipose tissue is performed from the reflected abdominal flaps, especially when the lipocutaneous abdominal flaps are more than $5 \mathrm{~cm}$ thick. After closure of the lower abdominal incision is accomplished, neoumbilicoplasty is performed by suturing the apices of three simple triangular flaps, after defatting the skin 


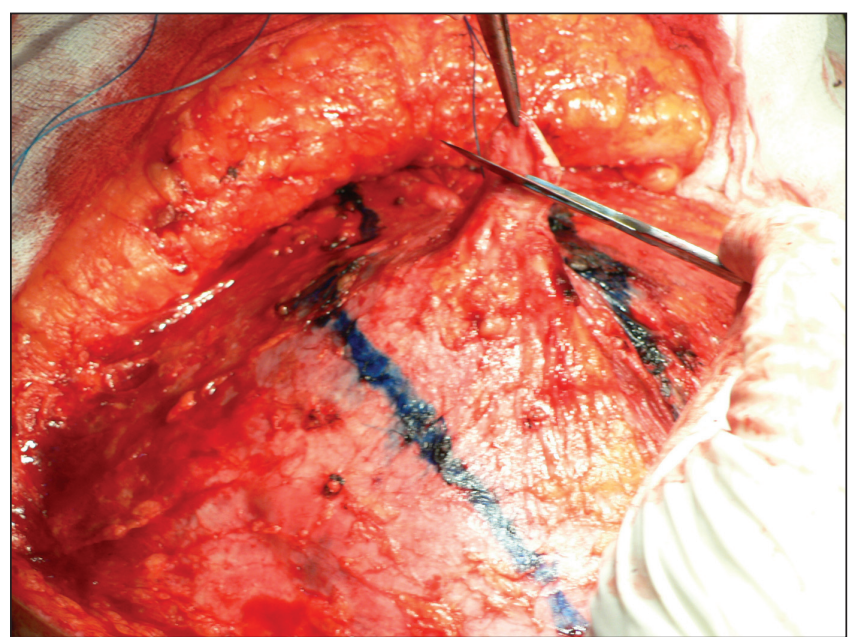

Figure 3) Sacrificing the natural umbilicus followed by neoumbilicoplasty are needed when short umbilical stumps are encountered

flaps to the muscular plane (Mateu technique) (10). It is vital that the apex of new umbilicus is fixed securely down to the fascia. Over time, the skin contracts, leaving an aesthetically pleasing neoumbilicus

\section{RESULTS}

A review of the records revealed 17 patients who had undergone abdominoplasty with myofascial plicaton that required sacrificing the old deformed and/or flat umbilicus, followed by neoumbilicoplasty.

Nine patients had concomitant ventral hernias (52.94\%) and eight patients had wide divarication of the rectus abdominis muscle with short umbilical stumps (47.05\%).

The myofascial plication distances were between $12 \mathrm{~cm}$ and $19 \mathrm{~cm}$ (mean $15.41 \mathrm{~cm}$ ) (Table 2), and all required three to five rows of sutures to accomplish gap closure. Conical excision of adipose tissue with the apex pointed to the neoumbilici were performed in all patients; this excision enhances the umbilical depression and improve the aesthetic appearance. Patients remained in hospital for a mean of five days (range four to seven days).

\section{DISCUSSION}

Myofascial plication is a major component of abdominoplasty in patients with significant divarication of the rectus abdominis muscle $(11,12)$ and/or concomitant abdominal hernias $(13)$, as well as an integral part in standard aesthetic abdominoplasties in an effort to narrow the waistline (12).

In our patients, when the plication distances of myofascial complex exceeded $10 \mathrm{~cm}$, several rows of plication were required. If the umbilical stump was long enough, the original umbilicus was re-placed.

If the umbilical stump is too short, trying to pull it up through the plicated muscles would render the umbilicus ischemic. Therefore, sacrificing the umbilicus followed by neoumbilicoplasty was determined to be the most appropriate choice.

Furthermore, in cases of concomitant umbilical hernias, repairing the muscular gap by a continuous running suture will ensure better results, and to make this procedure possible the
TABLE 2

The estimated perioperative distances in myofascial plication in 17 patients who required neoumbilicoplasty

\begin{tabular}{lc}
\hline Number of patients & $\begin{array}{c}\text { Estimated perioperative } \\
\text { plication distances, } \mathbf{c m}\end{array}$ \\
\hline 2 & 12 \\
3 & 13 \\
2 & 14 \\
4 & 16 \\
2 & 17 \\
3 & 18 \\
1 & 19 \\
Total 17 & Mean 15.41 \\
\hline
\end{tabular}

original umbilici has to be sacrificed, followed by neoumbilicoplasty.

The objectives of abdominal hernial repair or repair of diastasis recti are to reconstruct the structural integrity of the abdominal wall while minimizing morbidity (13). A review of the literature shows wide diversity in the long-term durability of such repair. Al-Qattan (14) reviewed 20 consecutive multiparous women with musculoaponeurotic laxity who underwent abdominoplasty. All patients had recurrence of the musculoaponeurotic laxity within one year of follow-up. Netscher et al (15) studied the durability of musculoaponeurotic plication in nine patients who underwent abdominoplasty, by placing metal markers in the fascia. Serial radiographs performed up to one year postoperatively revealed that there was minor degree of separation $(2 \mathrm{~cm}$ to $3 \mathrm{~cm}$ ), which was not compromising the aesthetic results (15). Van Uchelen et al (16) reviewed a total of 63 patients with ultrasound follow-up for a mean of 64 months and found that $40 \%$ of the patients developed residual or recurrent diastasis (16).

In an attempt to reduce these recurrence rates, sacrificing the umbilicus in selected patients and securing the whole length of plication distance from xiphisternum to symphysis pubis by using many rows of sutures and alternating rows of interrupted sutures would help in reducing tension on the repaired fascial layers and improve healing process, while at the same time reducing postoperative pain.

There are many techniques for umbilical reconstruction $(17-23)$. The common objective of these techniques is to create a new umbilicus that looks natural in terms of location, size and depth. Neoumbilicoplasty can be performed by lateral skin excisions and a rotation of two small paramedian flaps, as reported by Borges (20). Jamra (21) performed neoumbilicoplasty by designing two flaps with V-Y advancement. The use of an advancement flap and conchal cartilage composite graft to obtain a deep and a stable umbilicus was reported by Matsuo et al (23). An elliptical skin island with fat excisions underneath and depression created through a pursestring suture was reported by Marconi (17). Mateu and Hernandez (10) created a neoumbilicus by creating three simple triangular flaps and suturing their apices after defatting the skin flaps to the muscular plane, similar to Kirianoff's technique of using a pursestring suture to reconstruct the inner walls of neoumbilicus (22). Designing a cylinder-like hollow from folding upper and lower portions of a rectangular flap to reconstruct the neoumbilicus was done by Yotsuyanagi et al (18). 
All the techniques mentioned above undoubtedly create an umbilicus-like depression, but this subject still needs further improvement in terms of long-term results.

\section{CONCLUSION}

Sacrifice of the old umbilicus followed by neoumbilicoplasty is a useful adjuvant procedure that is justified during abdominoplasty in patients with significant diastasis recti, an ultra short umbilicus and/or concomitant abdominal hernias of the abdominal wall.

\section{REFERENCES}

1. Craig SB, Faller MS, Puckett CL. In search of the ideal female umbilicus. Plast Reconstr Surg 2000;105:389-92.

2. Koshy CE, Taams KO. Umbilicoplasty. Plast Reconstr Surg 1999;104:1203-4.

3. Dubou R, Ousterhout DK. Placement of the umbilicus in an abdominoplasty. Plast Reconstr Surg 1978;61:291-3.

4. Choudhary S, Taams KO. Umbilicosculpture: A concept revisited. Br J Plast Surg 1998;51:538-41.

5. Bartsich SA, Schwartz MH. Purse-string method for immediate umbilical reconstruction. Plast Reconstr Surg J 2003;112:1652-5.

6. Santanelli F, Mazzocchi M, Renzi L, Cigna E. Reconstruction of a natural-looking umbilicus. Scand J Plast Reconstr Surg Hand Surg 2002;36:183-5.

7. McMillan WM. Surgery of umbilical hernia with reconstruction of an artificial umbilicus. Q Bull Northwest Univ Med Sch 1955;29:379-82.

8. Iida N, Ohsumi N. Reconstruction of umbilical hypogenesis accompanied by a longitudinal scar. Plast Reconstr Surg 2003;111:322-5.
9. Kokuba EM, Sabino NM, Sato H, Aihara AY, Schor E, Ferreira LM. Reconstruction technique for umbilical endometriosis. Int J Gynaecol Obstet 2006;94:37-40.

10. Mateu LP, Hernandez C. Neoumbilicoplasty through a pursestring suture of three defatted flaps. Aesth Plast Surg J 1997;21:349.

11. Ramirez OM. Abdominoplasty and abdominal wall rehabilitation. A comprehensive approach. Plast Reconstr Surg J 2000;105:425-35.

12. Santos E, Muraira J. The waist and abdominoplasty. Aesth Plast Surg J 1998;22:225-7.

13. Robertson JD, de la Torre JI, Gardner PM, Grant JH 3rd, Fix RJ, Vásconez LO. Abdominoplasty repair for abdominal wall hernias. Ann Plast Surg 2003;51:10-6.

14. Al-Qattan MM. Abdominoplasty in multiparous women with severe musculoaponeurotic laxity. Br J Plast Surg 1997;50:450-5.

15. Netscher DT, Wigoda P, Spira M, Peltier M. Musculoaponeurotic plication in abdominoplasty: How durable are its effects? Aesth Plast Surg 1995;19:531-4.

16. van Uchelen JH, Kon M, Werker PM. The long-term durability of plication of the anterior rectus sheath assessed by ultrasonography. Plast Reconstr Surg J 2001;107:1578-84.

17. Marconi F. Reconstruction of the umbilicus: A simple technique. Plast Reconstr Surg J 1995;95:1115.

18. Yotsuyanagi T, Nihei Y, Sawada Y. A simple technique for reconstruction of the umbilicus, using two twisted flaps. Plast Reconstr Surg J 1998;102:2444.

19. Abenavoli FM, Cusano V, Cucchiara V, et al. An idea for umbilicus reconstruction. Ann Plast Surg J 2001;46:194.

20. Borges AF. Reconstruction of the umbilicus. Br J Plast Surg 1975;28:75.

21. Jamra FA. Reconstruction of the umbilicus by a double V-Y procedure. Plast Reconstr Surg J 1978;64:106.

22. Kirianoff TG. Making a new umbilicus when none exists. Plast Reconstr Surg J 1978;61:603.

23. Matsuo K, Kondoh S, Hirose T. A simple technique for reconstruction of the umbilicus, using a conchal cartilage composite graft. Plast Reconstr Surg 1990;86:149. 